\title{
Best Practices for Quality Improvement—Lessons from Top Ranked Engineering Institutions
}

\author{
Potti Srinivasa Rao ${ }^{1}$, K. G. Viswanadhan ${ }^{2} \&$ Raghunandana K. ${ }^{3}$ \\ ${ }^{1}$ Humanities and Management Department, M.I.T. Manipal, Manipal University, India \\ ${ }^{2}$ Mechanical Department, N. S. S. College of Engineering, Calicut University, India \\ ${ }^{3}$ Mechatronics Department, M. I. T. Manipal, Manipal University, India \\ Correspondence: Potti Srinivasa Rao, Humanities and Management Department, M. I. T. Manipal. India. Tel: \\ 919-448-843-102. E-mail: srinivasapotty@yahoo.co.in
}

Received: May xx, 2015 Accepted: June 13, 2015 Online Published: October 28, 2015

doi:10.5539/ies.v8n11p169 URL: http://dx.doi.org/10.5539/ies.v8n11p169

\begin{abstract}
Maximum number of privately funded engineering institutions have been established in India in the last two decades to meet the growing needs of technical manpower required by the Engineering and IT companies as well as aspiring students after completion of the Pre-University Program. However, a large number of institutions have not been able to attract the talented students for their undergraduate programs. The private managements of those institutions have realized then, the need for maintaining high quality in imparting engineering education. In addition, the regulatory bodies like NBA insist on maintaining the quality in the educational programs before giving accreditation. Therefore, the young institutes need to know the best practices adopted by the high performing institutions and introduce those best practices in their programs. In this paper, an attempt has been made to identify the best practices of the reputed and ranking institutes, to classify and codify those practices so as to enable the young institutes to implement them. Quality indicators have been identified through literature review, by summarizing previous studies, by conducting discussion with experts in the field. A few top ranked engineering institutions are selected to identify and list the best practices, by referring to the finding of various magazines. Practices followed with respect to the quality indicators identified have been composed by conducting structured interviews and discussions with various core groups \& stake holders of these institutions. The details of literature review, data collection \& analysis, findings and policy implications of the research work are presented in this paper. The best practices enlisted through this study will act as guidelines to implement the quality initiatives for the young institutions.
\end{abstract}

Keywords: benchmarking, best practices, non-ranked institutions, quality, ranked institutions

\section{Introduction}

Engineering education is of the utmost important in validating the technical man power required to build a strong nation. A modest beginning for the development of engineering education in India was made in $19^{\text {th }}$ century. Liberalization of economic and market policies drew to a high growth of I.T in the country (India). Although there was a dire need for engineers, the government did not fund the opening of new institutions, so as to meet the need of the market for engineers, many private engineering institutions were set up in various regions of India (Umashankar \& Dutta, 2007). By 2004, India had 1267 approved engineering colleges. Out of these, 1047 engineering colleges fell under privately funded category (http//www.aicte.ernet.in). This type of non-monitored growth was responsible for a lack in quality of the engineering and technical education. Several initiatives have been taken to constantly improve the quality of the technical education, to match the demand for engineers in the fast growing technologies and industry. These include accreditation of engineering programmes by National Board of Accreditation (NBA), giving autonomy or deemed university status to selected institutions, encouraging institutions to get ISO certification, quality improvement programmes (QIP) for teachers etc. Proper training to teachers is a pre-requisite for achieving excellence in teaching (Elton, 1998). Teaching can be made effective by taking student feedback regularly and by maintaining a crux between pedagogy and self-estimation (Telford \& Masson, 2005). The ISO certification has led the institutions to gain process orientation, streamline the operations and provide evidences on continuous improvement in teaching-learning techniques and the processes of administration (Burli et al., 2012). 
The term "excellence" has been reflected as "the outstanding practices in managing the organization and driving it to give high results" (Karuppusami \& Gandhinathan, 2006). A decade ago, the authors (Kanji \& Tambi, 1999) have mentioned that the Higher Educational Institutes should work along with the concepts, principles of Total Quality Management (TQM) especially for achieving excellence. Implementation of TQM concepts, principles and techniques is considered as the primary step on the road to excellence (Van der Wiele et al., 2000). Benchmarking and Quality Management Systems are some of the tools and techniques recommended in TQM philosophy (Besterfield et al., 2003). Gotzamani and Tsiotras (2002) explain that ISO 9000 is a subsystem of TQM. Organizations achieve success by implementing the concepts of ISO as well as TQM. These two complement each other and contributes to the organizational success in its own way. For example, TQM contributes by insisting on continuous improvement and ISO by insisting on creation and adherence to the things stated in various documents (Magd \& Curry, 2003). Managers exist at different levels in every organization. The management's involvement and guidance in quality must be visible at all levels and it should be visible remarkably at higher levels (Calvo-Mora et al., 2006). Vora (2002) conveyed that quality management is un-achievable without the involvement and commitment of the higher level management. Higher Educational Institutes (HEIs) will be able to fulfil their mission in providing skilled manpower for industries only when the top management exhibit their leadership effectively (Bush, 2003). Petrov (2006) mentioned that the nature of leadership in higher education is indefinite and disputed because of the organizational intricacy, the multiple goals and the old-fashioned ideals of the university. Enough resources will automatically be allocated to quality improvement when the top management of a college is committed to quality (Karuppusami \& Gandhinathan, 2006). The three types of facilities that contribute to the quality in an engineering college are (i) learning environment that includes classrooms with proper teaching aids located in academic blocks, well equipped labs, and space for social gatherings (ii) facilities like library and computer center that support learning (iii) other facilities like hostel blocks, medical facilities and student services (Harvey, 2003). After spending three years with a college, students (customers) will have an idea of the teaching, learning facilities, learning support facilities and other facilities provided by their college. Customer's (student's) opinion can be taken while evaluating overall service quality (Owlia \& Aspinwall, 1988). From the study (Sakthivel, 2007), it was found that the Overall Excellence increases when the commitment of top management is greater in providing the best education service to the student-customer. In a preceding study, it is also found that "Commitment of Top Management", and "Campus Facilities" were strong predictors of students' contentment of academic performance (Sakthivel et al., 2005).

Educators advocated 'college autonomy' as one of the possible solutions for strengthening the quality of education offered by the higher educational institutes. Dr. Radhakrishnan committee had recommended the concept of autonomy in the year 1948 (REE, 2003). Autonomy has three dimensions viz. Academic autonomy, Administrative autonomy and Financial autonomy. The National Policy on Education (NPE)-1986 suggested that the autonomy should be available to the institutions in selection of students, appointment and promotion of teachers, determination of courses of study and methods of teaching and choice of areas for research and their promotion (TE II, 1999). The University Grants Commission (UGC) has announced in June 2005 their acceptance in principle the report submitted by the Central Advisory Board on Education (CABE), in granting the independence to colleges, and stated that the autonomy is a pre-requisite for empowering the institutes to achieve their goals and objectives effectively (CABE, 2005). From an earlier study (Viswanadhan, Rao, \& Mukhopadhyay, 2005), it is felt that the performances of autonomous institutions are superior to those of other categories. From another study (Viswanadhan, Sindhu, Srinivasa, \& Raghunandana, 2011), it is found that the teachers from autonomous colleges are in favor of almost absolute autonomy.

Benchmarking is recognized as an essential tool for continuous improvement of quality (Dattakumar \& Jagadeesh, 2003). Benchmarking not only helps in improving the quality but also in evaluating quality improvement projects (Muthu et al., 2000). Benchmarking has been used as a tool, a methodology and a technique for continuous improvements in sectoral operations to gain and maintain competitive advantage. Creating and maintaining the main and supplementary physical resources, and learning facilities; financial and human resources; designing courses and curriculum; performing activities like teaching, learning and evaluating; conducting research and consultancy are a few basic aspects of an educational institute/university. Educational institutes/universities are benchmarking in one or more above mentioned aspects now-a-days due to changes in five primary factors of higher education: increasing parental concern about the quality of education; higher public expectations from what college/university should be delivering; greater emphasis on college/university rankings; demographic changes in student population; and higher costs (Oketch, 2009). A few types of Benchmarking (Lutfullayev, 2007) followed in Higher Educational Institutes are: 1) Internal Good Practice Benchmarking 2) External Benchmarking. 3) International Benchmarking. 4) Performance or Competitive 
Benchmarking. 5) Process Benchmarking. 6) Functional and Generic Benchmarking. 7) Strategic Benchmarking. 8) Best Practices Benchmarking.

In a study (Magutu, 2011), it was found that the public universities in Kenya have been following development/improvement benchmarking. It was also felt that the Kenyan Public Universities need to adopt international benchmarking. Four internationally-renowned and leading engineering universities have developed a new engineering education model, CDIO (Conceiving-Designing-Implementing-Operating). Any engineering school/college/university can benchmark curricula for teaching of personal, interpersonal and system building skills (Bankel et al., 2005). Colleges offering engineering education were asked to include some concepts of Green Engineering or Engineering Sustainability in the curriculum. The extent to which sustainability concepts have been incorporated in the U.S engineering programs have been studied. Authors have put some efforts into Green Engineering Benchmarking (Murphy, et al., 2009) to assess their level of incorporation in their programmes. National Assessment and Accreditation Council (NAAC) is an organization that assesses and accredits institutions of higher education in India. The criterion statements under each of the seven criteria of the NAAC focus on the norms that generate the practices instead of identifying the practices of the 'best-in-class' institution (Prasad \& Stella, 2006). Best practices possible under each of the seven criteria of the NAAC have been compiled by referring to the evidence derived from the exhaustive reports of NAAC on various higher educational institutes located in India (Prasad, 2004). Prathap (2013) made an attempt to benchmark the recent research performance of the IITs in academic research in the area of engineering science and technology in the country against that of similarly placed institutions in the world using bibliometric indicators from the Web of Science and Scoupus databases. Most of the young institutes offering engineering education are limited to undergraduate programs. After discussions on whether faculty research supports undergraduate teaching or not, authors (Prince et al., 2007) have suggested a few strategies to realize the potential synergies between faculty research and undergraduate education. A study on "Benchmarking in Higher Education" was made by Commonwealth Higher Education Management Service (CHEMS). Several case studies on benchmarking in various universities from four different countries have been described in the report (UNESCO/ACU-CHEMS, 1998). SPINE (Successful Practices in International Engineering Education) is another benchmarking study (Bodmer et al., 2002) of engineering education in ten leading European and U.S universities. Through an exhaustive study, the SPINE report has summarized the successful practices in specific areas of engineering education offered by those ten universities. The practices highlighted in the SPINE report were mostly implementable at corporate level and functional level. The young engineering institutes in India have to consider the operational level best practices along with the corporate and functional level best practices. It may be enough for the young engineering institutes if they initially understand the best practices prevailing in the best-in-class institutes located in India. Therefore, a study has been initiated to understand these best practices which can be applied at young engineering institutes.

A few engineering institutions have become top-ranked through their high performance. Therefore, the top-ranked institutions may be treated as best-in class organizations. A particular practice is referred as a best practice when it is observed commonly in most of such top-ranked institutions.

Definitions and Features of Best Practices:

1) Some methods or techniques when implemented give superior results compared to the other means. Those can be used as a benchmark. (http://www.businessdictionary.com/definition/best-practice.html\#ixzz2myhesOzp).

2) A set of guidelines, ethics or ideas that represent the most efficient or prudent course of action (www.wikipedia.com).

3) A business buzzword that describes a set of defined methods, processes, systems used by a company or organization to meet performance and efficiency standards within their industry or organization (www.wikipedia.com).

4) According to the Association of Maternal Child Health Program's (AMCHP) Best Practices Program (2000), a practice becomes the best practice when

- It is scrutinized and validated by experts in the education field according to the criteria established by empirical research;

- It gives desirable results in a variety of settings.

5) National Assessment \& Accreditation Council (NAAC) organized a "National Conference on Best Practices in Higher Education" in the year 2004. They listened to the experiences of application of best practices of ninety heads of colleges and universities (Inductive Approach) and extracted 60 best practices for Higher Educational Institutes (Prasad, 2004). As per the details of the report: 
- Many best practices are college-specific and individually managed.

- During the implementation, many best practices demand additional effort by the employees.

- When implemented best practices bring lots of value to the college and its stakeholders.

- Best institutions are those which widely use best practices.

- Excellence can be measured by taking the average of the best practices implemented in various areas of performance of a college.

6) One can identify and select the best practices in the area of manufacturing planning and control based on the framework (Davies \& Kochhar, 2000). Selection of best practices is based on:

- Strength of impact on the desired measure of performance;

- Consideration of adverse effects, if any, on other measures of performance;

\section{Objective of the Study}

A large number of privately funded young engineering institutions have not been successful in providing cost effective quality education. The two main reasons are: (1) They have not been able to follow the best practices of the top ranking institutions. (2) As they have not been able to fulfill the expectations of stakeholders, their seats are not filled to the full capacity. Benchmarking is the systematic search for best practices, innovative ideas, and highly effective operating procedures. In this study, an attempt has been made to identify and summarize the best practices adopted by top ranked privately funded engineering institutions located in India.

\section{Methodology}

Engineering institute managements that are interested in knowing their institution position in the market do approach various magazines. These magazines publish the list of best institutions along with its rank nationally. By referring to the survey conducted by such magazines, the top 30 ranked engineering institutions have been approached for the study (Srinivasa, Viswanadhan, Raghunandana, \& Shivaprasad, 2014). Among the thirty, fifteen institutions responded favorably. Stakeholders are the most important resource persons in providing information about engineering institutions. Students, alumni, teachers, staff, management representatives, parents, industries that employ graduates, and management of the institution are different stakeholders. Alumni, parents and industries have limited interactions with the institution on day-to-day basis and can access some of the quality characteristics of education provided by the respective institution. Management of the institution has limited approachability. Hence, the students, teachers, staff and the management representatives are selected as the respondents for the study. With the permission of their institution management, the questionnaires were given to the respondents. 140 students, 100 teachers, 30 staff and 26 management representatives in total from 15 top ranked privately funded engineering institutions have participated in the discussions by responding to the questions asked in the questionnaire. Questions were related to the physical facilities, work environment, research etc. The steps in collecting the data are mentioned in the flow chart (Figure 1).

\section{List of Best Practices Observed in Ranked Institutions}

Practices followed in each of the top-ranked privately funded engineering institutions under study were explored by conducting structured interviews and discussions with students, staff, teachers, and management representatives. Then, the practices that were shared by all the four groups of respondents belonging to a particular institution have been consolidated under the name of that institution. Finally, the practices that were found in most of the institutions considered for the study against each variable have been declared as best practices. In the following discussions, the word "institutions" refers to the privately funded ranked engineering institutions. The best practices adopted by those institutions are given under six headings.

\subsection{Organizational Governance and Related Factors}

\subsubsection{Decentralization}

1) Eighty percentages of the institutions are following the decentralized approach in decision-making by their teachers in deciding the new courses, detailed syllabus, and teaching methodology and evaluation criteria.

2) Equipment in the laboratories and the fabrication facilities in various workshops are accessible freely to students and teachers after the college official working hours in 60 percentages of the institutions. 


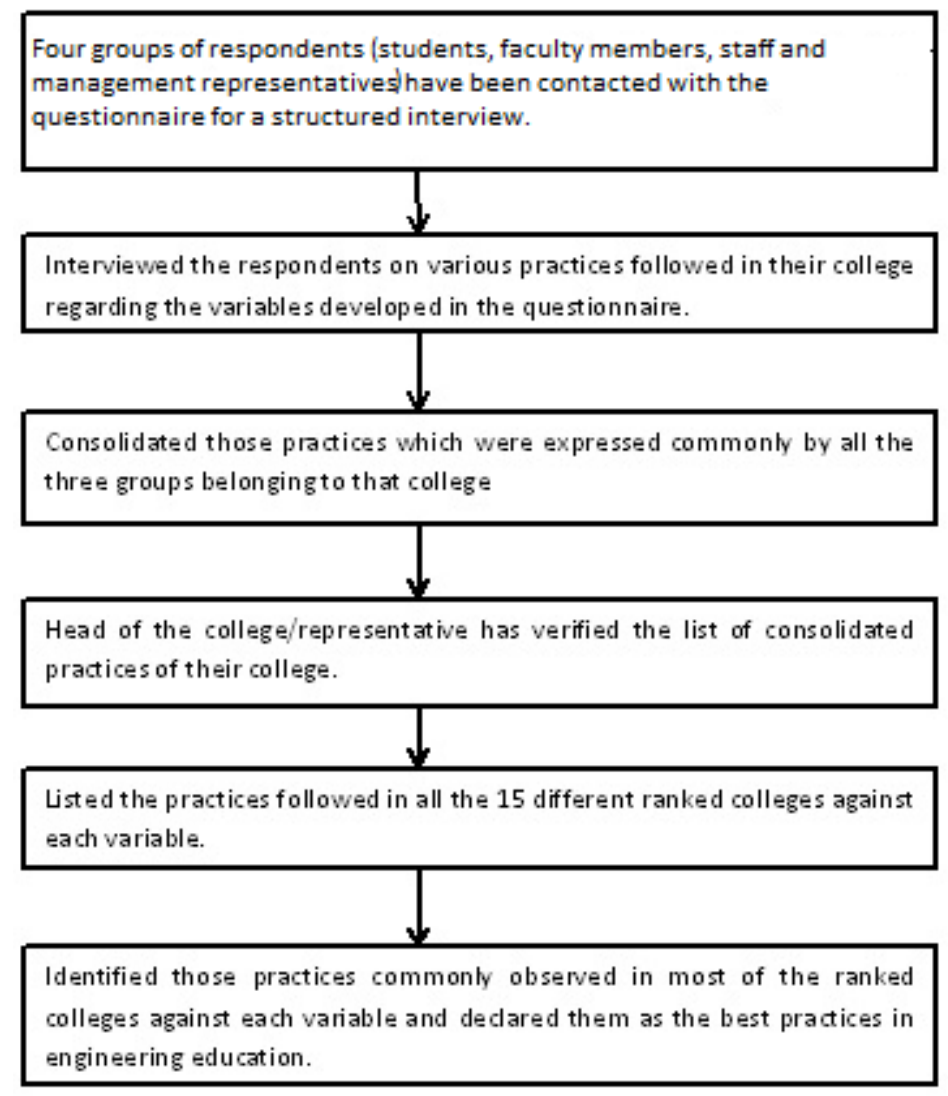

Figure 1. Steps in identifying the best practices in engineering education

\subsubsection{Teacher Involvement}

The inter-disciplinary teams consisting of teachers from various departments are playing an active role in all the institutions. This kind of practice benefits the teachers not only in faster completion of tasks but also in the growth of pleasant relations between the departments.

Such a type of group working is found in 20 percentages of the institutions not only in the process of development of curriculum but also in the development of detailed syllabus. Such a group working is observed in the next 60 percentage of the institutions only in the development of detailed syllabus. Autonomy is encouraging the teachers to work in teams across the departments, especially, in the development of curriculum and/or detailed syllabus. This is observed in 80 percent of the institutions totally.

\subsubsection{Monetary Incentives for Teachers}

1) About 73.3 percentages of the institutions are offering monetary incentives to their teachers when they take up consultancy works from other organizations and generate income.

2) When teachers take up research projects, they will be able to create new research facilities for their institution and bring fame in society. They may not be able to generate any income for the institutions. In 53.3 percentages of the institutions, the financial incentives are given to teachers to work on research projects.

3) In 40 percentage of the institutions, monetary incentives are given to teachers when they acquire higher qualifications such as Doctoral and Post-doctoral. Further, they also get promoted when they get higher qualification.

\subsubsection{Performance Measurement for Teachers}

Performance Measurement System (PMS) have been introduced to measure the level of achievement by the teacher, department or division. This system also includes feedback from the students every semester.

1) Student feedback is collected regarding the teacher performance in each course generally at the end of the semester in most of the institutions. In 86.7 percentages of the institutions, performance of their teachers is 
appraised once in a year. Only in two institutions, among the institutions considered for the study, it is done twice in a year which comes up to 13.3 percentages.

2) Besides salary, financial incentives are also given to the best performers among the teachers. This practice is prevalent in 40 percentages of the institutions.

\subsubsection{Skills up Gradation for Staff}

Most of the staff members are interested in "acquiring new professional skills" through additional qualifications. Those additional qualifications may help them in obtaining promotions. This particular employee interest is supported by many on the field policies of organizational development (Ana, 2001). It is also in the interest of the institution to create provisions in fulfilling their wishes so that they get motivated to work.

1) All the institutions (93.3 percentages) except one conduct the promotional interviews for their staff members at regular intervals.

2) Some of the managements (two out of fifteen institutions) own a group of institutions offering various UG and PG programs. Such managements encourage their staff members to register for the courses in those institutions by providing tuition fee concessions. About 40 percentage of the institutions management provide education loans at low interest rate to their staff members for up grading their qualifications.

\subsubsection{Employer's Feedback}

Students not only expect good education but also proper placement opportunities from the management. Industries visit college campuses for recruiting the students. The employers may develop a good opinion about the institution and form a positive feedback when (a) the college management takes quality students with high cultural diversity (b) the college provides training for placements (c) the recruited students join the industry and perform well. The feedback received from the recruiting companies enable the institute to take corrective actions to improve the quality of education and training of students. Thus, the percentage of placements will increase in the future.

1) The extent of student representation from different states of India: Students get a higher chance to learn intercultural patterns of people if a college has students representing different states of India. This skill is found useful in marketing the products, especially, when students join the business firms. In 26.7 percentages of the institutions, a high extent of representation of students from different states of India is observed. In 53.3 percentages of the institutions, the extent of representation of students from different states of India is moderate.

2) Nearly 46.7 percentages of the institutions have built good relations with the industries. These industries offer internship to the students who have been recruited by them in the campus interviews. The period of internship varies from 4 to 6 months. This practice strengthens the relation between the industries and institute. In 53.3 percentages of the institutions, students do visit a series of industries by spending a few days in each as a part of their curriculum.

\subsubsection{Admission Criteria}

1) Majority of the institutions (86.7 percentages) are using 3 different windows for admitting the students: NRI quota, Management quota, and Merit quota. The top rankers in the entrance examination or $10+2$ examination are admitted under merit quota. In 6.6 percentages of the institutions, single window system is followed for student admission. Two different windows are used for admitting the students in the remaining 6.6 percent institutions.

2) Majority of the students are admitted into institutions through counselling process. Counselling Centres are organized at a few selected locations. Students are allowed to choose the institute and branch of their choice based on the rank secured in the entrance test and marks secured in $10+2$.

\subsubsection{Availability of Academic Calendar}

1) The Academic Calendar is issued in the form of a circular individually to all the employees in 80 percentages of the institutions. In the remaining 20 percentage of the institutions, one copy of the academic calendar is issued per department by the institution.

2) The Academic Calendar is issued individually to the students along with the Academic Hand Book in all the institutions.

\subsubsection{Alumni and Their Involvement}

Involving well placed alumni in institutional activities will facilitate faster growth and development of the institution. 
1) In one third of the institutions, their alumni occupying executive positions in industries have helped them by providing (a) Training and internship to the students (b) Campus placements (c) Project sponsorship.

2) About 26.7 percentages of the institutions have been getting financial benefits from their alumni for developing laboratories and other infrastructure.

3) Alumni who have had rich experiences from their service might show interest in sharing their knowledge with the present students. Such alumni can be used for delivering the guest lecture or keynote addresses during conference. Eighty percentages of the institutions have expressed that their alumni are giving such guest lectures.

\subsection{Teachers and Related Factors}

\subsubsection{Teachers and Their Efficiency}

The top ranked institutions are known by the accomplishments of their teachers. Therefore, the management has to take active role in the growth and development of teachers. The following factors have played a major influence on the development of teachers:

1) Curriculum revision is required from time to time and new courses will have to be introduced due to changing technologies and changing requirements of industries. In 60 percentages of the institutions, curriculum is revised every year and complete revision is done once in four years.

2) In 46.7 percentages of the institutions, the teachers are required to teach the same course/s consecutively for 3 years. At the end of 3 years, they will have to take up another course/s. In this way, the teachers obtain proficiency in many courses over a period of time.

3) In 13.3 percentages of the institutions, an inexperienced teacher is mentored by the senior teacher. Inexperienced teacher will be assisting the senior teacher in the class work, laboratory and project work. In 26.6 percentage of the institutions, the inexperienced teachers are made efficient by providing training periodically.

\subsubsection{Teacher Commitment}

The following points have been observed in institutions in enabling their teachers to contribute efficiently and best of their ability.

1) In 33.3 percentages of the institutions, the management is encouraging their teachers to undertake sponsored projects by providing logistic support. Further, the teachers are awarded points that help in promotion. In the remaining 66.6 percentage institutions, management is not only awarding the points that help in promotion but also rewarding their teachers monetarily.

2) In 86.6 percentages of the institutions, management is motivating their teachers to involve in planning and development of institute by assigning points that help in promotions. In addition to points, teachers are also given monetary incentives in the remaining 13.3 percentage institutions.

\subsubsection{Publications}

It is the moral responsibility of each and every teacher to pursue research and publish their research findings. The institutional management need to encourage teachers to involve in research and put enough efforts in publishing their research findings in the prestigious journals.

1) The institution managements consider the number of publications of the teachers in 60 percentages of the institutions during performance appraisal.

2) About 46.7 percentages of the institution managements offer monetary incentives to their employees for their publications.

\subsection{Students and Related Factors}

\subsubsection{Pass Percentage}

The pass percentage in end semester examination indicates to what extent the student has understood the concepts, and practical application in the chosen field.

\subsubsection{Marks or Grading System}

Grading system is followed in 80 percentages of the institutions. In all these 80 percentage institutions, the examination system has a mechanism to ensure the maximum opportunity for students to clear the examinations with measures such as make-up examination, blue print for setting the question papers based on varied difficulty level and re-examination for genuinely ill students. All these measures result in achieving enhanced student performance in the examination. 


\subsection{Campus Facilities and Related Factors}

\subsubsection{Bus Facility}

Making a provision for transportation facility is considered a good practice for institutions. This is true even when an institution is operating with 100 percent in campus programs. Use of institution bus exclusively for students has lot of advantages. Institution's buses can spend a few extra hours especially in the evening near the library and laboratory. This particular facility helps both the students and teachers in pursuing curricular and co-curricular objectives. This facility is observed in one of the institutions. Wherever the public transport facility is scarce, all the institutions included in the study have their own transport facility.

\subsubsection{Number of messes}

In 80 percent of the institutions, a large number of messes are available catering to the individual needs of students. These messes with smaller capacity are located in various places covering the total campus. The remaining 20 percentage of institutions provide facilities such as food courts to cater to the large number of students. These food courts are located in central points in the campus. Survey reports indicate that the number of students missing their breakfast is higher in institutions which have food courts than in institutions that have messes with smaller capacity. It has been observed that students who do not miss their breakfast have been performing better in academics (Adolphus, Lawton, \& Dye, 2013)

\subsubsection{Health Care Facilities}

The regulatory body AICTE has made it compulsory to have medical facility within the institution campus.

1) As much as 86.7 percentages of the institutions have a smaller clinic located inside the campus that extends general services to its inmates. The remaining 13.3 percentages of the institutions operate with a full pledged hospital inside the campus.

2) About 40 percentages of the institution managements own well established hospitals that provide higher level health services to its members.

3) Only one institute doesn't possess their own hospital. However, it reimburses the medical expenses incurred by its employees.

\subsubsection{Hostel Rooms Facility}

Institution management can save on bus facility by locating the mess and hostel blocks nearer to the Academic Blocks.

1) Type of hostel facility available: Hostel rooms of moderate quality at reasonable price are made available to the inmates in 93.3 percentages of the institutions. Hostel rooms with regular as well as luxurious facilities are found in one of the institutions.

2) Uninterrupted power supply: This facility is sought in these days by most of the students and parents especially during the examination time. Such a facility is made available by 46.7 percentages of the institutions. This enables the smooth functioning of the academic activities in the concerned college.

\subsubsection{Availability of Learning Material}

1) About 26.7 percentages of the institutions make learning material available on their campus website.

2) Most of the institutions ( 93.3 percentages) considered for study recommend learning materials which contain a minimum of 60 percentage of the prescribed syllabus of a course.

\subsection{Teaching \& Learning and Related Factors}

\subsubsection{Student Performance Appraisal}

Tests, seminars, quizzes, assignments and projects are the five different means used for appraising the student performance in all the institutions.

\subsubsection{Working days}

1) About 46.7 percentages of the institutions work five days a week. Another 46.7 percentages of the institutions work for five and a half days a week.

2) In 66.7 percentages of the institutions, teachers spend 14 to 16 weeks per semester (by foregoing public holidays) for direct classroom contact with students. They are able to cover the major portion of the syllabus in this period.

\subsubsection{Academic Research for Higher Qualifications}


Management insist on teachers to take up academic research also acquire higher qualifications. One third of the institutions also pay monetary incentives.

\subsubsection{Guiding Weaker Students}

NBA recommends identifying the weaker students (academically) and to take extra coaching classes to enable those students to complete the course within the stipulated time period.

1) Analysis of student marks in in-semester test and end-semester test help the institutions in identifying the weaker students in academics. This procedure is followed in 93.3 percentages of the institutions.

2) Academically weaker students are identified and counselled initially. Extra classes are conducted through the class teacher or commonly allocated teachers in 40 percentages of the institutions. Academically weaker students are identified, counselled, and, then they are kept under observation under senior teachers in 60 percentages of the institutions.

\subsection{Other Processes and Related Factors}

\subsubsection{Training the Students for Placement}

1) Some of the institutions ( 86.7 percentages) organise the training camps for placements and prepare their students for placements. In this context, the institutions invite the professionals from outside for providing the training to their students regarding placements. Placement awareness camps and mock tests are organized in the remaining institutions (13.3 percentages).

2) About 46.7 percentages of the institutions start the soft skills training program while their students are in $3^{\text {rd }}$ semester. About 40 percentages of the institutions start the soft skill training program to their students while they are in $5^{\text {th }}$ semester.

3) Eighty percentages of the institutions provide the training for technical skills to their students in the middle of their $6^{\text {th }}$ semester.

4.6.2 Entrepreneurial Development

1) A separate cell with a title "Entrepreneurship Cell" is observed in 93.3 percentages of the institutions.

2) Innovation Centre is in operation in 53.3 percentages of the institutions.

3) Awareness on Entrepreneurship among the students and teachers is generally created by conducting the seminars in the institution premises. These seminars may be organized by the Entrepreneurship Cell or Innovation Centre. Seminars on Entrepreneurial Development are organized by the Entrepreneurship Cell in 93.3 percentages of the institutions.

4) Technology Business Incubator (TBI) is observed in well-established shape in 33.3 percentages of the institutions. This centre acts as a catalyst in the development of entrepreneurs.

\subsubsection{Consultancy Services}

Some institutions generate revenue by offering consultancy services to the nearby industries and local administrative bodies. This is possible only when laboratories and research facilities are available after the institute working hours and during holidays. Teachers involved in this activity are also given additional points in their performance evaluation.

1) People are able to access the research facilities of the institute even after the working hours in 60 percentages of the institutions.

2) A policy of offering monetary incentives to its consultancy service providers is found in 73.3 percentages of the institutions.

3) One third of the institutions are considering the consultancy services of their teachers during the performance appraisal.

\subsubsection{Industrial Visits}

Many institutions take their students for industrial visit so that the students get an exposure to the industry environment

1) Twenty percentages of the institutions have made industry visit compulsory for their students. The option to do internship in the industry or an institute for three to four months is available in two institutions. Industrial training for 3 weeks is made compulsory in 13.3 percentages of the institutions.

2) About 13.3 percentages of the institution managements own industries and they are able to arrange 
visit/training/internship for their students easily. Alumni who own industries help the institution managements in arranging visit/training/internship to their students in 13.3 percentages of the institutions.

\subsubsection{Patents}

Institution management encourages employees to get patent for their research work.

1) During the performance appraisal, the patents secured by their employees are considered by the institution management in one third of the institutions.

2) In one third of the institutions, a separate patent cell located in the institute is assisting the employees by providing procedures and by creating awareness on patenting through seminars. The remaining 66.7 percentages of the institutions conduct seminars on 'Intellectual Property Rights' to its employees and students.

\subsubsection{Sponsored Research Projects}

Institutions can derive many benefits from the sponsored research projects such as a) upgrading their laboratory facilities b) generating funds for the institute c) crating new knowledge and obtaining patent rights.

1) Research projects are taken into account during the performance appraisal of the teachers in 60 percentages of the institutions.

2) Managements motivate their employees by offering monetary incentives for having taken up the sponsored research projects in 53.3 percentages of the institutions.

3) Whenever the revenue generated from a research project is to be invested in the institution, the management is consulting the people concerned in 80 percentages of the institutions.

\section{Discussions}

A long list of best practices from top-ranked privately funded engineering institutions is given in this paper, have been summarized in Table 1. Those institutions had the following features:

Table 1. Best practices observed in privately funded top-ranked engineering colleges

\begin{tabular}{|c|c|c|}
\hline Category & Category Description & $\begin{array}{l}\text { Best Practice Description, Exact percentage of the top-ranked } \\
\text { institutes following the particular practice }\end{array}$ \\
\hline \multirow{15}{*}{ I } & \multirow{15}{*}{$\begin{array}{l}\text { Practices observed in } \leq 25 \% \text { of } \\
\text { the ranked institutions surveyed }\end{array}$} & $\begin{array}{l}\text { Teachers working in inter-disciplinary teams for developing } \\
\text { curriculum and detailed syllabus, } 20 \%\end{array}$ \\
\hline & & Appraising teacher's performance every semester, $13.3 \%$ \\
\hline & & $\begin{array}{l}\text { Promotions and monetary incentives to teachers involved in } \\
\text { institute's planning \& development, } 13.3 \%\end{array}$ \\
\hline & & $\begin{array}{l}\text { Tuition fee concessions while studying UG \& PG programs in } \\
\text { institutions owned by the same management, } 13.3 \%\end{array}$ \\
\hline & & Single window (merit quota) for student admissions, $6.6 \%$ \\
\hline & & $\begin{array}{l}\text { Two windows (merit quota, NRI quota) for student admissions, } \\
6.6 \%\end{array}$ \\
\hline & & Issuance of a copy of Academic Calendar per department, $20 \%$ \\
\hline & & Senior teachers mentoring inexperienced teachers, $13.3 \%$ \\
\hline & & $\begin{array}{l}\text { Operating college bus near library and laboratory after office } \\
\text { hours, } 6.6 \%\end{array}$ \\
\hline & & Large Food Courts, $20 \%$ \\
\hline & & Operating a full pledge hospital inside the campus, $13.3 \%$ \\
\hline & & Placement awareness camps, $13.3 \%$ \\
\hline & & Compulsory visit to industries by students, $20 \%$ \\
\hline & & Compulsory training in industries for 3 weeks, $13.3 \%$ \\
\hline & & $\begin{array}{l}\text { Compulsory internship in industry/institute for 3-4 months, } \\
13.3 \%\end{array}$ \\
\hline
\end{tabular}


Industrial visit/training/internship arrangement in college management owned industries, $13.3 \%$

Industrial visit/training/internship arrangement in alumni owned industries, $13.3 \%$

Monetary incentives while pursuing research for Ph.D, 33.3\%

Monetary incentives for acquiring Ph.D and above qualifications, $40 \%$

Providing logistic support to sponsored project takers, 33.3\%

Monetary incentives for teacher's publications, $46.7 \%$

Considering consultancy services provided during performance appraisal, 33.3\%

Financial incentives for best performing people after the appraisal, $40 \%$

Educational loans at lower interest rates while upgrading the qualifications, $40 \%$

High representation of students from different states in a college, $26.7 \%$

Practices observed in $>25 \%$ and

II

$$
\leq 50 \%
$$

of the ranked institutes surveyed
Alumni Funds for institutional development, 26.7\%

Alumni in executive positions providing training and internship; campus placements; sponsored projects, $33.3 \%$

Allowing teachers to teach same subject for 3 consecutive years, $46.7 \%$

Training inexperienced teachers, $26.6 \%$

Hospital facility, located outside the campus, run by the same college management, $40 \%$

Uninterrupted power supply, $46.7 \%$

Learning material availability on college web-site, $26.7 \%$

Institutes working five days a week, 46.7\%

Institutes working five and half days a week, $46.7 \%$

Extra classes for weaker students, $40 \%$

Soft skill training right from 3rd semester, $46.7 \%$

Soft skill training right from 5 th semester, $40 \%$

Well established Technology Business Incubator, 33.3\%

Considering patents obtained during performance appraisal, $33.3 \%$.

Teachers working in inter-disciplinary teams for developing detailed syllabus, $60 \%$

Monetary incentives for taking up research projects, 53.3\%

Practices observed in $>50 \%$

Points for research project takers (points help in promotions as well as monetary incentives), $66.6 \%$

Considering the no. of research projects completed during performance appraisal, $60 \%$

Monetary incentives for consultancy services provided, $73.3 \%$

Considering the no. of publications of teachers during performance appraisal, $60 \%$

Laboratory, fabrication, and research facilities accessible after 
official working hours, $60 \%$

Moderate representation of students from different states in a college, $53.3 \%$

Curriculum revision every year, $60 \%$

Maintaining 14-16 weeks of classroom contact per semester, $66.7 \%$

Keeping weaker students under teacher's observation, $60 \%$

Innovation Centre in operation, $53.3 \%$.

Decentralization in deciding courses, syllabus, teaching and evaluation, $80 \%$

Autonomy in working, $80 \%$

Promotions to teachers involved in institute's planning \& development, $86.6 \%$

Appraising teacher's performance once a year, 86.7\%

Regular promotional interviews for staff and faculty members, $93.3 \%$

Three different windows (merit, NRI and Management quota) for student admissions, $86.7 \%$

Academic Calendar issue to all employees in the form of a notice, $80 \%$,

Practices observed in $>75 \%$

and

$\leq 100 \%$

of the ranked institutes surveyed
Academic Calendar issue to all students along with Academic Hand Book, 100\%

Following Grading System, 80\%

Guest lectures by alumni, $80 \%$

Operating large number of smaller messes, $80 \%$

Maintaining a clinic inside the campus, $86.7 \%$

Hostel rooms with moderate quality, 93.3\%

Recommended books covering a minimum 60 percent syllabus, $93.3 \%$

Identifying weaker students from their performance in exams, $93.3 \%$

Training for campus placements, $86.7 \%$

Maintenance of an Entrepreneurship Cell, 93.3\%

Training for technical skills in 6th semester, $80 \%$

Seminars on Entrepreneurial Development, 93.3\%.

- Major decisions concerning the start of a new course, curriculum and evaluation were decentralized. This helped the involvement of faculties in groups, to have good equipment in the laboratories and fabrication facilities in the workshop with the help of the alumni. The course curriculum was updated regularly, considering the latest technologies in vogue. This stimulated both the faculty and students to make use of the facilities very efficiently, particularly in interdisciplinary areas.

- Faculty members as well as staff were encouraged to go for higher education and skill development in particular areas. Monetary incentives were given to the faculty with higher qualifications and those who were dynamically involved in publications of technical papers, research work and consultancy. Based on the feedback from the immediate seniors as well as students, the faculty performance was assessed. Faculty members with high performance were considered for suitable monetary incentives and also a decision to promote them was taken. The faculty members were encouraged to get specialized in a course of their 
choice by teaching the same course for a few years. The newly recruited faculty members were also trained under experienced faculty before they started their teaching career.

- Most of the institutions followed the grading system. Those institutions provided the student with reasonable number of opportunities to clear the examination with measures such as make - up examination and re-examination for genuinely ill students. All these measures resulted in achieving enhanced student performance in the examination.

- The institutions operating off campus and in campus had transport facility even after the working hours. This helped the faculty and the students to utilize the facilities of the college viz. library, laboratory, workshop, hospital and in particular extra-curricular activities for the students. Good numbers of hostels with equally virtuous number of messes were provided by the institutions.

- Learning materials, in the form of slides were provided for the students and regular tests, quizzes, seminars and assignments were given to them to evaluate their progress continuously. Academically weaker students were identified, counseled and extra coaching was provided to ensure that they excel.

- The students were provided with suitable training to confirm that they are well placed. Institutions established Technology Business Incubator (TBI). This center provides logistic support to the students who are interested in starting their own enterprise. They also encouraged the students to visit the industry and get an exposure to the industrial activities.

Non-ranked privately funded engineering institutions can definitely improve the quality in their services over a period of time by adapting to these best practices. Selection and implementation of a particular best practice from the literature by the management of an institution depends solely on their long term goals, vision, stakeholder interests, academic requirements, local community, learner composition, infrastructure, trained non-teaching staff, and governance.

\section{Research Limitations/Future Research}

- One of the steps in benchmarking is: identification of the best-in-class organizations. In the study, top-ranked privately funded institutions are treated as best-in-class institutions and have been selected from the list of best institutions published by various magazines. A few college managements may not participate in the survey conducted by those magazines. Therefore, the best institutions for the study may also be selected from word of mouth.

- Benchmarking is a way of finding and adopting best practices (Fielden, 1994). The practitioners (students, staff, teachers, and management representatives) were asked to describe the best practices followed (inductive approach) in their respective college with reference to various parameters of quality considered in the study. External stakeholders like alumni, parents, and the companies visiting the colleges for placement can also be contacted in identifying the best practices in each college considered for the study. Self-study report of the institution may also be referred to in identifying the practices followed with reference to various criterion statements.

- Potentially valuable practices can be identified initially from the colleges under study using surveys and interviews. Then the successful practices can be identified after detailed analysis and verification.

- Details regarding college/university structure, international student exchange, distance education programs, relevance of education to practice in industry, and quality of thesis projects from the institutions considered for the study have not been collected due to some difficulties. Those details may also be considered in the future studies.

\section{References}

Adolphus, K., Lawton, C. L., \& Dye, L. (2013). The effects of breakfast on behavior and academic performance in children and adolescents. Frontiers in Human Neuroscience, 7, 425. http://dx.doi.org/10.3389/fnhum.2013.00425

Ana, G. G. (2001). International best practices of higher education Institutes: The Good News: 2001. Retrieved from http://www.academia.edu/2781211/

Bankel, J., Berggren, K. F., Engstrom, M., Wiklund, I., Crawley, E. F., Soderholm, D., . . Ostlund, S. (2005). Benchmarking Engineering Curricula with the CDIO Syllabus. International Journal of Engineering Education, 21(1), 121-133.

Besterfield, D. H., Besterfield-Michna, C., Besterfield, G. H., \& Besterfield, M. (2003). Total Quality 
Management. Prentice-Hall, Englewood Cliffs, NJ.

Bodmer, C., Leu, A., Mira, L., \& Ruttu, H. (2002). Report of the Successful Practices in International Engineering Education (SPINE). Benchmarking Study, May.

Burli, S., Bagodi, V., \& Kotturshettar, B. (2012). TQM dimensions and their interrelationships in ISO certified engineering institutes in India. Benchmarking: An International Journal, 19(2), 177-192.

Bush, T. (2003). Theories of Educational Leadership and Management (3rd ed.). Sage, London.

CABE. (2005). Report of the Central Advisory Board of Education (CABE) Committee on Autonomy of Higher Education Institutions, June.

Calvo-Mora, A., Leal, A., \& Roldan, J. L. (2006). Using enablers of the EFQM model to manage institutions of higher education. Quality Assurance in Education, 14(2), 99-122. http://dx.doi.org/10.1108/09684880610662006

Dattakumar, R., \& Jagadeesh, R. (2003). A review of literature on benchmarking, Benchmarking: An International Journal, 10(3), 176-209.

Davies, A. J., \& Kochhar, A. K. (2000). A framework for the selection of best practices. International Journal of Operations \& Production Management, 20(10), 1203-1217. http://dx.doi.org/10.1108/01443570010343744

Elton, L. (1998). Dimensions of excellence in university teaching. International Journal for Academic Development, 3(1), 3-11. http://dx.doi.org/10.1080/1360144980030102

Fielden, J. (1997). Benchmarking University Performance. CHEMS monograph.

Gotzamani, K. D., \& Tsiotras, G. D. (2002). The true motives behind ISO 9000 certification: Their effect on the overall certification benefits and long term contribution towards TQM. International Journal of Quality \& Reliability Management, 19(2), 151-169. http://dx.doi.org/10.1108/02656710210413499

Kanji, G. K., \& Tambi, A. M. B. A. (1999). Total quality management in UK higher education institutions. Total Quality Management, 10(1), 129-153. http://dx.doi.org/10.1080/0954412998126

Karuppusami, G., \& Gandhinathan, R. (2006). Pareto analysis of critical success factors of total quality management: A literature review and analysis. The TQM Magazine, 18(4), 372-385. http://dx.doi.org/10.1108/09544780610671048

Lutfullayev, P. (2007). Research on Benchmarking in Higher Education: An Overview. Regional Conference on quality in higher education "Quality driven initiatives: sharing good practices in higher education", 10-11 Dec 2007, Hilton Petaling Jaya, Malaysia.

Magd, H., \& Curry, A. (2003). ISO 9000 and TQM: Are they complementary or contradictory to each other? The TQM Magazine, 15(4), 244-256. http://dx.doi.org/10.1108/09544780310486155

Magutu, P. O., Mbeche, I. M., Nyamwange, S. O., \& Nyaoga, R. B. (2011). A Survey of Benchmarking Practices in Higher Education in Kenya: The Case of Public Universities. IBIMA Business Review, 1-20. http://dx.doi.org/10.5171/2011.357694

Murphy, C. F., Allen, D., Allenby, B., Crittenden, J., Davidson, C. I., Hendrickson, C., \& Matthews, H. S. (2009). Sustainability in Engineering Education and Research at U.S. Universities. Environmental Science \& Technology, 43(15), 5558-5564. http://dx.doi.org/10.1021/es900170m

Muthu, S., Devadasan, S. R., Ahmed, S., Suresh, P., \& Baladhandayutham, R. (2000). Benchmarking for strategic maintenance quality improvement. Benchmarking: An International Journal, 7(4), 292-303. http://dx.doi.org/10.1108/14635770010378927

Oketch, M. (2009). Private-public Mix in the Provision of Higher Education in East Africa: Stakeholders Perceptions Compare. A Journal of Comparative and International Education, 39(1), 21-33.

Owlia, M. S., \& Aspinwall, E. M. (1998). A framework for measuring quality in engineering education. Total Quality Management, 9(6), 501-518. http://dx.doi.org/10.1080/0954412988433

Petrov, G. (2006). The leadership foundation research on collective leadership in higher education. Leadership Matters, 7, 11.

Prasad, V. S. (2004). Higher Education in India Quality Perspectives, ICFAI University, India.

Prasad, V. S., \& Stella, A. (2006). Best Practices Benchmarking in Higher Education for Quality Enhancement. The ICFAI University Press, India. 
Pratap, G. (2013). Benchmarking research performance of the IITs using Web of Science and Scopus bibliometric databases. Current Science, 105(8), 1134-1138.

Prince, M. J., Felder, R. M., \& Brent, R. (2007). Does Faculty Research Improve Undergraduate Teaching? An Analysis of Existing and Potential Synergies. Journal of Engineering Education, 96(4), 283-294. http://dx.doi.org/10.1002/j.2168-9830.2007.tb00939.x

REE. (2003). Re-engineering of Engineering Education, Report of the Board of Planning of Technical Education. AICTE, New Delhi, India.

Sakthivel, P. B. (2007). Top management commitment and overall engineering education excellence. The TQM Magazine, 19(3), 259-273. http://dx.doi.org/10.1108/09544780710745676

Sakthivel, P. B., Rajendran, G., \& Raju, R. (2005). TQM implementation and students' satisfaction of academic performance. The TQM Magazine, 17(6), 573-589. http://dx.doi.org/10.1108/09544780510627660

Srinivasa, P. R., Vishwanadhan, K. G., Raghunandana, K., \& Shivaprasad, H. C. (2014). A few unique practices in high performance engineering colleges. International Journal of Research in Advent Technology, Special Issue, 51-56.

TEII. (1999). Technical Education in Independent India 1947-1997. All India Council for Technical Education, New Delhi, India.

Telford, R., \& Masson, R. (2005). The congruence of quality values in higher education. Quality Assurance in Education, 13(2), 107-119. http://dx.doi.org/10.1108/09684880510594364

Umashankar, V., \& Dutta, K. (2007). Balanced scorecards in managing higher education institutions: An Indian perspective. International Journal of Educational Management, 21(1), 54-67. http://dx.doi.org/10.1108/09513540710716821

UNESCO/ACU-CHEMS. (1998). Benchmarking in Higher Education. Report of the Commonwealth Higher Education Management Service, United Nations Educational, Scientific and Cultural Organization, place de Fontenoy, Paris.

Van der Wiele, T., Dale, B. G., \& Williams, R. (2000). Business improvement through quality management systems. Management Decision, 38(1), 19-23. http://dx.doi.org/10.1108/00251740010311799

Viswanadhan, K. G., Rao, N. J., \& Mukhopadhyay, C. (2005). Impact of privatization on engineering education-A study through the analysis of performance of self-financing engineering programmes in India. Journal of Services Research, Special issue, 109-129.

Viswanadhan, K. G., Sindhu, R., Srinivasa, P. R., \& Raghunandana. (2011). Autonomy of Technical Education: A Comparative Analysis through Teachers' Outlook'. The Indian Journal of Technical Education, 34(3).

Vora, M. (2002). Business excellence through quality management. Total Quality Management, 13, 1151-1159. http://dx.doi.org/10.1080/09544120200000010

\section{Copyrights}

Copyright for this article is retained by the author(s), with first publication rights granted to the journal.

This is an open-access article distributed under the terms and conditions of the Creative Commons Attribution license (http://creativecommons.org/licenses/by/3.0/). 